\title{
Estudio del daño por choque térmico en materiales compuestos de matriz de vidrio reforzados con fibras de carburo de silicio
}

\section{Assessment of thermal shock induced damage in silicon carbide fibre reinforced glass matrix composites}

\author{
A. R. BOCCACCINI (1), D. N. BOCCACCINI ${ }^{(2)}$, D. H. PEARCE ${ }^{(3)}$, J. JANCZAK-RUSCH ${ }^{(4)}$ \\ (1) FG Werkstoffechnik, TU Ilmenau, Alemania \\ (2) UTN FR San Rafael, Argentina
(3) IRC in Materials, The University of Birmingham, Reino Unido \\ (4) EMPA-Thun, Suiza
}

Fecha de recepción: 9-II-98

Fecha de aceptación: 14-IV-98

\section{RESUMEN}

El desarrollo de daño microestructural en materiales compuestos de matriz de vidrio reforzados con fibras de carburo de silicio (Nicalon ${ }^{T M}$ ) sometidos a choque térmico fue investigado mediante la técnica no-destructiva de resonancia forzada y por mediciones de indentación "push-out " de fibras. Los ensayos de choque térmico involucraron el enfriamiento brusco en un baño de agua a temperatura ambiente de las piezas previamente calentadas a una temperatura elevada $\left(650^{\circ} \mathrm{C}\right) . \mathrm{La}$ técnica de resonancia forzada permitió medir cambios en el módulo de Young de elasticidad y en la fricción interna de las muestras, ocurridos al aumentar el número de choques térmicos como consecuencia del daño microestructural inducido. La investigación del "push-out" de fibras mostró que las propiedades de la interfase fibra/matriz no variaron apreciablemente bajo las condiciones de choque térmico estudiadas. Los resultados demostraron que la única forma de daño microestructural inducido por choque térmico en el material compuesto fue el agrietamiento de la matriz de vidrio. Además se observó que la fricción interna es un parámetro altamente sensible para detectar el inicio y desarrollo de tal agrietamiento. Se presenta un modelo semi-empirico simple, el cual permite correlacionar el nivel de fricción interna medido con la densidad de agrietamiento de la matriz de vidrio.

Finalmente, se dedica especial atención a la importancia de detectar en forma no-destructiva la presencia de microgrietas en la matriz de vidrio, en conexión con la posibilidad de inducir un proceso de curado de tales microgrietas mediante un tratamiento térmico, aprovechando el flujo viscoso del vidrio.

\section{SUMMARY}

The development of microstructural damage in silicon carbide fibre (Nicalon ${ }^{T M}$ ) reinforced glass matrix composite samples subjected to thermal shock was investigated by using a nondestructive forced resonance technique and fibre push out indentation tests. Thermal shock testing involved quenching samples in a water bath maintained at room temperature from a high temperature $\left(650^{\circ} \mathrm{C}\right)$. Changes in the Young's modulus and internal friction of the samples with increasing number of shocks were measured accurately by the forced resonance technique. Fibre push-out tests showed no significant changes in the properties of the fibre-matrix interface, indicating that damage in the composite was concentrated mainly in the development of matrix microcracking. It was also shown that the internal friction is a very sensitive parameter by which to detect the onset and development of such microcracking. A simple semi-empirical model is proposed to correlate the internal friction level with the microcracking density in the glass matrix. Finally, the relevance of detecting nondestructively the existence of microcracks in the glass matrix, before any significant interfacial degradation occurs, is emphasized, in conextion with the possibility of inducing a crack healing process by a thermal treatment (annealing), taking advantage of the viscous flow properties of the glass. 


\section{INTRODUCCIÓN}

Los materiales cerámicos compuestos constituyen una nueva clase de materiales ligeros, predestinados para aplicaciones que requieren elevada resistencia mecánica a altas temperaturas en atmósferas oxidantes $[1,2]$.

Aunque originalmente pensados para aplicaciones aeroespaciales y en máquinas térmicas, estos materiales tambien pueden resultar atractivos para aplicaciones en la Construcción, por ejemplo como componentes antifuego o en elementos de protección térmica que deben trabajar bajo cargas mecánicas. Para la introducción satisfactoria de estos materiales, y materiales compuestos relacionados de matriz vítrea, en tales aplicaciones, es necesario un detallado conocimento de su comportamiento mecánico a altas temperaturas y de su resistencia a cambios bruscos de temperatura o choques térmicos. Esto explica la creciente cantidad de trabajos publicados en la literatura especializada en los últimos años referidos al comportamiento de este tipo de materiales compuestos sometidos a gradientes térmicos [3-16]. Los estudios han incluido materiales compuestos de matrices cerámicas [3-6], vitro-cerámicas [7-10] y vitreas [10-16] reforzados con fibras de carburo de silicio y materiales compuestos carbono/carbono utilizados en la industria nuclear $[17,18]$. En la mayoría de esos estudios se utilizaron principalmente técnicas destructivas, como ensayos mecánicos de flexión, para investigar el daño inducido en el material por choque térmico. Estos métodos permiten una caracterización macroscópica de la degradación de las propiedades mecánicas del material, sin embargo, no son métodos lo suficientemente sensibles como para detectar el daño microestructural en su estado inicial, es decir, la incipiente formación de microgrietas en la matriz y/o en la interfase matriz-fibra.

Por otra parte, la observación de la microestructura usando superficies pulidas frecuentemente no permite un adecuado estudio del daño inducido, debido a que, en el caso de microgrietas incipientes, éstas pueden desaparecer como consecuencia del procedimiento de pulido [10], ya que son muy finas y/o de poca profundidad. Además, debido a sus muy pequeñas dimensiones, éstas son difíciles de detectar usando microscopía óptica y en microscopía electrónica su detección es sólo posible si el contraste es adecuado [19]. Las técnicas de evaluación no-destructivas, incluyendo la determinación del módulo de elasticidad usando ondas de ultrasonidos, o el método de resonancia forzada, o bien utilizando emisiones acústicas generadas durante el desarrollo de daño por choque térmico, no han sido empleadas extensivamente para evaluar el daño microestructural en materiales compuestos reforzados por fibras. En particular, para el caso de materiales compuestos de matriz vítrea reforzados con fibras de

\section{INTRODUCTION}

Ceramic and glass matrix composites constitute a new class of light materials, predestinated for applications requiring high mechanical strength at high temperature in oxidizing atmospheres [1, 2]. Although these materials were originally developed for applications in aerospace and thermal machinery technology, they can be also attractive for applications as building materials, for example as anti-flame panels or thermal insulation components which must sustain mechanical loads. For these materials to be satisfactorily introduced in such applications, however, an in-depth knowledge of their mechanical behaviour at high temperatures and of their resistance to abrupt temperature gradients is required. This explains the increasing amount of research work published in the last years dealing with the thermal shock and thermal cycling behaviour of these materials [3-16]. These studies have included composite materials with ceramic [3-6], glass-ceramic [7-10], and glass matrices [10-16], reinforced with silicon carbide fibres, as well as carbon/carbon composites used in the nuclear industry $[17,18]$. In most of the published studies, destructive characterisation techniques, i.e. flexural strength tests, were mainly employed to assess the damage induced by thermal shock. While these methods allow for a macroscopic assessment of the degradation of the mechanical properties, namely fracture strength and "composite" behaviour, they may not be sensitive enough to detect damage development in its early stages, e.g. the onset of matrix cracking, debonding and/or interface damage in the composites.

Microstructural observation of polished sections does not usually provide a conclusive assessment about the nature of the induced damage, since the crack pattern developed may disappear as a consequence of the polishing procedure employed [10]. Moreover, due to their small dimensions, microcracks are also difficult to detect using optical microscopy, and in scanning electron microscopy poor contrast can add complications [19]. Non-destructive evaluation techniques, including the determination of the dynamic elastic moduli using ultrasonic wave techniques or mechanical forced resonance methods, or by recording the accoustic emissions generated during thermal shock damage, have not been extensively used for evaluating thermal shock damage in fibre reinforced ceramic composites. In fact, all previous studies on thermal shock of SiC fibre reinforced glass composites, except 
carburo de silicio, que es el material investigado en el presente trabajo, todos los estudios previos, exceptuando los propios [11,20], fueron lievados a cabo empleando técnicas de evaluación destructivas [10, 12-16].

Además, a pesar de su importancia en la determinación del comportamiento mecánico macroscópico del material compuesto, no se ha investigado anteriormente en este tipo de materiales en forma cuantitativa el efecto del choque térmico sobre las propiedades de la interfase matriz/fibra. Un método conveniente para tales estudios es el empleo de la técnica de indentación de fibras ("push-out"), que permite medir la tensión de unión de la interfase (o sea, la tensión para la cual la fibra se separa completamente de la matriz) y la resistencia a la fricción en la interfase [21,22].

El objetivo de este trabajo es estudiar la detección del daño microestructural inducido por choque térmico en materiales compuestos de matriz vítrea reforzados por fibras de carburo de silicio (Nicalon ${ }^{\mathrm{TM}}$ ), utilizando mediciones del módulo de Young y de la fricción interna por medio de la técnica de resonancia forzada $\left(Q^{-1}\right)$ [23]. Debido a que el daño por choque térmico puede manifestarse también en forma de una degradación de las propiedades de la interfase, éstas fueron evaluadas antes y después de los choques térmicos mediante la técnica de indentación de fibras ("push-out"). Tambien se estudió la relación entre la fricción interna medida y la densidad de microgrietas generadas en el material por los choques térmicos.

Se vislumbran diversas aplicaciones para los materiales compuestos investigados en este estudio, especialmente en máquinas e instalaciones que deben trabajar a temperaturas entre 300 y $700^{\circ} \mathrm{C}$. Un ejemplo donde componentes de este tipo ya están siendo utilizados, es en la industria del vidrio, para la fabricación de piezas de equipos que deben trabajar en contacto con artículos de vidrio que se encuentran todavía a altas temperaturas [24]. Para que el uso de estos materiales sea satisfactorio en las aplicaciones mencionadas y pueda extenderse también a otras áreas, es necesario un conocimiento en profundidad de su comportamiento al choque térmico y su resistencia a la oxidación, siendo éste el objetivo de un amplio programa de investigación de carácter internacional recientemente implementado [25].

\section{PROCEDIMIENTO EXPERIMENTAL}

\subsection{Material}

El material investigado fue un material compuesto de matriz vítrea (vidrio borosilicato DURAN) reforzado por fibras de carburo de silicio (SiC -Nicalon ${ }^{\mathrm{TM}}$ ) our own investigations $[11,20]$, were carried out employing destructive techniques [10,12-16].

Despite its relevance in determining the mechanical behaviour of composite materials, the quantitative effect of thermal shock conditions on interfacial properties has not been studied so far for this class of composite. A convenient method for such interfacial studies is to employ the fibre push-out indentation technique, which allows for a direct measurement of the debonding shear strength and the frictional shear stress at the interface $[21,22]$.

The objective of this investigation was to assess the early stages of damage development in a commercial borosilicate glass matrix reinforced with $\mathrm{SiC}$ $\left(\right.$ Nicalon $\left.^{T M}\right)$ fibres under cyclic thermal shock loading using the dynamic measurement of Young's modulus $(E)$ and internal friction $\left(Q^{-1}\right)$ [23]. As thermal shock damage may also arise in the form of interfacial degradation, the interfacial properties before and after thermal shock were evaluated by a push-out indentation technique. The relationship between the measured internal friction level and the density of microcracks created in the material by the thermal shocks was also investigated.

A number of potential applications in special (hightemperature) machinery are envisaged for this material, including the construction of tool pieces for equipments and machinery that must work at intermediate temperatures $\left(300-700^{\circ} \mathrm{C}\right)$. A typical example where glass matrix composites are being utilized in the handling of hot glassware during glass component (e.g. bottles) manufacture [24]. For a satisfactory use of the materials in these applications, an in-depth knowledge of the thermal shock and oxidation behaviour of the material is required, this being the subject of a comprehensive on-going research programme [25].

\section{EXPERIMENTAL PROCEDURE}

\subsection{Material}

The material investigated was a unidirectional Nicalon $\mathrm{SiC}$ (NL202) fibre reinforced borosilicate (DURAN) glass matrix composite fabricated by Schott Glaswerke, 
fabricado por la empresa Schott-Glaswerke, (Mainz, Alemania). Los detalles sobre el proceso de fabricación de estos materiales pueden leerse en trabajos anteriores $[12,26]$. La tabla I muestra información sobre las propiedades de los componentes (matriz y fibras) y del material compuesto. Las muestras se recibieron en forma de barras prismáticas $\left(4,5 \times 3,8 \times 100 \mathrm{~mm}^{3}\right)$. $\mathrm{La}$ densidad del material es $2,4 \mathrm{~g} / \mathrm{cm}^{3}$ y el contenido de fibras es de $40 \mathrm{vol} \%$. Las muestras fueron investigadas en las condiciones recibidas, es decir, sin un acondicionamiento previo a los ensayos.

La figura 1 muestra los típicos diagramas tensióndeformación en ensayos de tracción para muestras de material compuesto y para muestras de vidrio sin reforzar [27]. Claramente la inclusión de fibras de carburo de silicio en la matriz de vidrio da lugar a una mayor resistencia mecánica, mayor módulo elástico y un comportamiento a la fractura no-catastrófico, más semejante al de materiales dúctiles. Este comportamiento favorable está dado no sólo por el mayor módulo de elasticidad y resistencia mecánica de las fibras en comparación con la matriz de vidrio, sino también por la presencia de una resistencia de unión óptima entre las fibras y la matriz. Esto se debe a la existencia de una fina capa rica en carbono (de 20-30 $\mathrm{nm}$ de espesor) en la interfase fibra/matriz, que es la que origina mecanismos de disipación de energía durante la fractura, por ejemplo deflección de grietas y arrancado de fibras ("pull-out"), y conduce, de ese modo, al comportamiento denominado "quasi-dúctil" del material compuesto [1,11,27-29].
Mainz, Germany. The composites were prepared by the sol-gel-slurry method. The processing technique details are found in the literature [12,26]: Information about the composite constituents and on the properties of the composite material is given in table I. The samples were received in the form of rectangular test bars of nominal dimensions (4.5x3.8x100 $\left.\mathrm{mm}^{3}\right)$. The density of the composites was $2.4 \mathrm{~g} / \mathrm{cm}^{3}$ and the fibre volume fraction approximately $40 \%$. The samples were first tested in the as-received condition.

Figure 1 shows typical stress-strain plots obtained in tensile stress tests on these materials and on unreinforced glass samples [27]. The incorporation of SiC fibers in the glass matrix results in a much higher fracture strength and Young's modulus and in a noncatastrophic failure behaviour, more similiar to that of metals than that of the brittle glass matrix. This better mechanical behavior is the result not only of the highmodulus, high-strength fibers incorporated, but also of the presence of an optimised fiber/matrix interfacial bond. The optimal interfacial bonding strength is given by a thin carbon-rich layer (20-30 nm thickness) situated at the interface, which enables energydisipative mechanism during fracture, e.g. crack deflection, and fiber pull-out, leading to the so-called "quasi-ductile" fracture mode of the composite [1,11,27-29].

TABLA I (TABLE /)

Propiedades de los constituyentes y del material compuesto $[11,12]$ (Properties of the constituents and composite [11,12])

\begin{tabular}{|c|c|c|c|}
\hline $\begin{array}{l}\text { Propiedad } \\
\text { (Property) }\end{array}$ & $\begin{array}{l}\text { Matriz: DURAN } \\
\text { (vidrio borosilicato) } \\
\text { (Matrix: DURAN } \\
\text { (borosilicate glass) }\end{array}$ & $\begin{array}{l}\text { Fibra: SiC } \\
\text { (NL 202) } \\
\text { (Fiber: SiC } \\
\text { Nicalon }^{T M} \text { ) }\end{array}$ & $\begin{array}{c}\text { Compuesto } \\
\text { (40 vol\% fibras) } \\
\text { (Composite } \\
(40 \% \text { vol fibers)) }\end{array}$ \\
\hline $\begin{array}{l}\text { Densidad }\left(\mathrm{g} / \mathrm{cm}^{3}\right) \\
\text { (Density) }\end{array}$ & 2,23 & 2,55 & 2,40 \\
\hline $\begin{array}{l}\text { Módulo de Young (GPa) } \\
\text { (Young's modulus) }\end{array}$ & 63 & 198 & 119 \\
\hline $\begin{array}{l}\text { Número de Poisson } \\
\text { (Poisson's ratio) }\end{array}$ & 0,22 & 0,20 & 0,21 \\
\hline $\begin{array}{l}\text { Coef. de expansión térmica }\left(\mathrm{K}^{-1}\right) \\
\text { (Thermal expansion coeff.) }\end{array}$ & $3,25 \times 10^{6}$ & $3 \times 10^{6}$ & $3,10 \times 10^{-6}$ \\
\hline $\begin{array}{l}\text { Resistencia a la tensión (MPa) } \\
\text { (Tensile strength) }\end{array}$ & 60 & 2.750 & $600-700$ \\
\hline
\end{tabular}




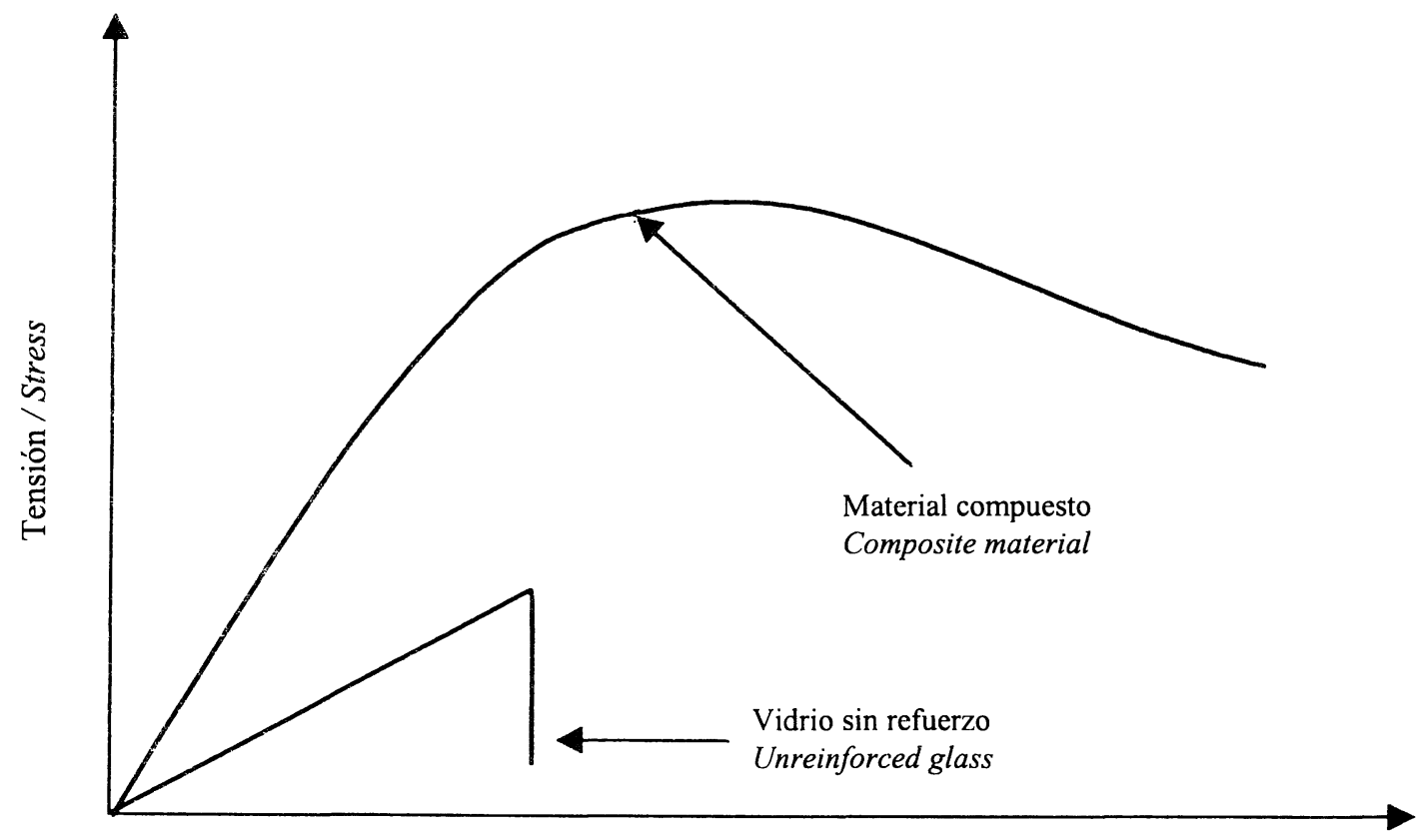

Deformación / Strain

Fig. 1.- Diagrama esquemático mostrando el diferente comportamiento mecánico de un material compuesto de matriz de vidrio reforzado con fibras de carburo de silicio y del material sin reforzar [27].

Fig. 1.- Schematic diagram showing the different mechanical behavior of a fiber reinforced glass matrix composite and the unreinforced glass [27].

\subsection{Ensayo de choque térmico}

El ensayo de choque térmico consistió en calentar las muestras en un horno de laboratorio a una temperatura predeterminada $\left(650^{\circ} \mathrm{C}\right)$ durante 20 minutos y luego sumergirlas bruscamente en un baño de agua mantenida a temperatura ambiente $\left(22^{\circ} \mathrm{C}\right)$. La temperatura para el choque térmico fue determinada considerando mediciones propias anteriores [11]. El gradiente térmico $\left(\Delta \mathrm{T}=630^{\circ} \mathrm{C}\right)$ fue elegido de modo que el daño microestructural inducido pudiera ser atribuido al efecto del choque térmico solamente y no a otras influencias como, por ejemplo, oxidación de la interfase o de las fibras o ablandamiento de la matriz de vidrio. Después de cada ensayo de choque térmico, las probetas fueron secadas en un horno a una temperatura de $100^{\circ} \mathrm{C}$ durante 10 minutos. La masa de las probetas y las dimensiones fueron medidas y las probetas inspeccionadas cuidadosamente para detectar la aparición de daño macroscópico, como delaminación, astillado, etc. En el caso de encontrarse alguna imperfección estructural o pérdida de masa las muestras fueron desechadas. Solamente las muestras que mantuvieron su apariencia y masa original fueron retenidas para las siguientes comprobaciones. De esta manera, la influencia de cualquier daño macroscópico en

\subsection{Thermal shock testing}

The thermal shock tests involved heating the samples in air in a muffle furnace at a pre-determined temperature $\left(650^{\circ} \mathrm{C}\right)$ for 20 minutes and then dropping them into a stagnant water-bath maintained at room temperature $\left(22^{\circ} \mathrm{C}\right)$. The furnace temperature was chosen on the basis of previous studies of the same composites [11]. The thermal gradient $\left(\Delta T=630^{\circ} \mathrm{C}\right)$ was chosen in order to isolate thermal shock induced damage from environmentally assisted damage in the form of interface or fibre oxidation, or matrix softening. After each thermal shock cycle, the samples were dried in an oven set at $100^{\circ} \mathrm{C}$ for 10 minutes. The mass and dimensions of the samples were measured, and the samples were inspected carefully for the appearance of any macroscopic damage, such as delamination, chipping, etc. If any macroscopic structural imperfection or mass loss was found, the sample was discarded. Only samples which maintained their original appearance and mass were retained for further examination. In this way, the influence of any macroscopic sample damage was eliminated, caused for example by their handling, thus ensuring that only 
la muestra es eliminado, como, por ejemplo, el ocasionado por su manipulación, asegurándose que sólo los procesos de degradación microestructural causados por el choque térmico son considerados, por tanto, microagrietamientos en la matriz de vidrio o cambios en la interfase. Después de un determinado número de choques térmicos, algunas muestras fueron fracturadas en ensayos de flexión de tres puntos y las superficies de fractura observadas mediante microscopio electrónico de barrido (MEB).

\subsection{Técnica de caracterización no-destructiva}

El número crítico de choques térmicos para inducir daños microestructurales detectables se determinó midiendo el cambio relativo del módulo de Young $(E)$ y de la fricción interna $\left(Q^{-I}\right)$ de las muestras después de cada ensayo. Las mediciones del módulo de Young y de la fricción interna se realizaron, tanto en las muestras sin ensayar como en las ya sometidas a choques térmicos, usando la técnica de vibración forzada, descrita, originalmente, por Förster en 1937 [30]. Se utilizó una configuración de barra suspendida, como muestra el esquema de la figura 2. En estudios previos se han dado descripciones más detalladas sobre la aplicación de esta técnica y sobre los aparatos utilizados en este tipo de medición [23,31,32]. Mediante la variación de la frecuencia de una señal acústica sinusoidal aplicada a la barra, se determina su frecuencia de resonancia $f_{r}$. Esta frecuencia está relacionada con el módulo de Young $(E)$ del material mediante una relación fija, dada por [30]: microstructural degradation processes or events, e.g. microcracking or interface changes, would be assessed. After a certain number of thermal shocks, some samples were fractured in three point bending tests in order to investigate the post-thermal shock fracture behavior. Fracture surfaces were observed by scanning electron microscopy (SEM).

\subsection{Non-destructive characterization}

The critical number of cycles for inducing detectable microstructural thermal-shock damage was determined by measuring the relative change in the Young's modulus $(E)$ and internal friction $\left(Q^{-1}\right)$ of the samples after each quenching cycle. These measurements were performed on both as-received and thermally shocked samples using a forced-vibration technique as described originally by Förster (1937) [30]. A suspended bar configuration, as shown in Figure 2, was used. In previous studies, detailed descriptions of the technique and of the employed apparatus have been given [23,31,32]. By varying the frequency of a sinusoidal signal applied to the bar, the resonant frequency, $f_{r}$, was determined. This frequency is related to the Young's modulus (E) of the material by a fixed relationship [30]:

$$
E=0,94642(1 / t)^{3}(m / b) f_{r}^{2} A
$$

donde $l, t$ y $b$ son las dimensiones de la muestra; longitud, espesor y anchura, respectivamente, $m$ es la masa de la probeta y $A$ es un factor de corrección [23].

Para cada muestra medida, se tomaron diez lecturas de la frecuencia, las cuales resultaron en diez valores del módulo de Young (E), que fueron promediados. Para mediciones de la fricción interna se empleó el método de caída libre de la señal a partir de la frecuencia de resonancia. Para esto, la energía acústica de entrada se elimina bruscamente y la fricción interna se determina por la velocidad de caida de la amplitud de vibración [23]. Es decir, la fricción interna se determina tomando la traza de caída en la amplitud de resonancia recogida por un transductor. Más detalles sobre esta técnica experimental empleada en la determinación de la fricción interna pueden encontrarse en trabajos anteriores [11,23,31], donde también se ha señalado la alta precisión alcanzada en la determinación de los datos de la fricción interna usando este método. Esto es importante para el presente estudio, ya que la variación de la fricción interna, debida a daño por choque térmico, where $l, t, b$ are the dimensions of the sample (length, height and thickness, respectively), $m$ is the mass of the sample and $A$ is a correction factor [23].

For each sample, ten readings were taken to determine average values of $E$. For the internal friction measurements, the method of free-decay was employed. Maintaining the signal at a constant level at the resonant frequency, the input signal was abruptly switched off. The resulting decay trace was stored, and the internal friction determined from the factor of the exponential decay envelope [23]. More details of the experimental technique employed for the internal friction determination are presented elsewhere [11, 23, 31], where also the high accuracy achieved in the determination of internal friction data using the present apparatus and software has been highlighted. This is relevant for the present investigations, because the variation of the internal friction due to thermal shock- 
se supone muy pequeña, por la formación incipiente de microgrietas en la matriz.

\subsection{Ensayos de indentación de fibras}

Los ensayos de indentación de fibras ("push-out") sobre muestras sin ensayar y sobre otras ya sometidas a choques térmicos, se han llevado a cabo con el objeto de determinar si el daño por choque térmico también se manifiesta en forma de cambios en las propiedades de la interfase fibra/matriz. Estos ensayos se han realizado usando un aparato de indentación alojado en un microscopio electrónico de barrido (MEB) (Touchstone Ltd, West Virginia, USA). El espesor de las muestras fue de $340 \mu \mathrm{m}$. Se ha usado una cuña de diamante para aplicar la carga sobre las fibras a una velocidad de desplazamiento de $0,18 \mu \mathrm{m} / \mathrm{seg}$. La figura 3 muestra la punta de diamante actuando sobre una fibra de $\mathrm{SiC}$ $\left(\right.$ Nicalon $^{\mathrm{TM}}$ ) en una muestra sin ensayar. El aparato ofrece alta exactitud para el posicionamiento de la punta lo cual permite que el proceso de "empujado" de la fibra se ejecute sin dañar a éstas o a la matriz. Se han ensayado veinte fibras en cada muestra y se determinó la tensión de corte de union de la interfase $\left(\tau_{\mathrm{db}}\right)$ y la resistencia al rozamiento en la interfase $\left(\tau_{\mathrm{ff}}\right)$, que son las propiedades que caracterizan a ésta [21,22]. Mayores detalles referidos a esta técnica de "push-out" de fibras se presentan en trabajos previos [22,32]. Finalmente se utilizó MEB en secciones pulidas de muestras sin ensayar y en muestras ya sometidas a choques térmicos para caracterizar las microestructuras. También se empleó el MEB para estudiar superficies de fractura.

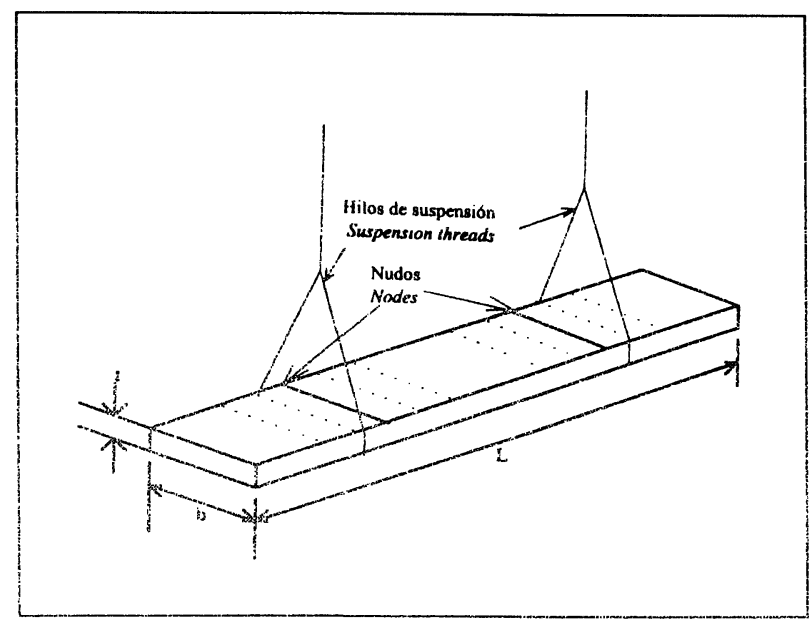

Fig. 2.- Diagrama esquemático mostrando la contiguracion de barra suspendida, utilizada en las mediciones de resonancia forzada [23].

Fig. 2.- Schematic diagran showing the stspended bar configuration used for the mechasical forcd resonance measuements 12.37 . induced damage is supposed to be small, for example by the formation of microcracks in the matrix.

\subsection{Fiber push-out indentation test}

Push-out indentation tests on as-received and thermally shocked samples were performed in order to assess whether thermal shock damage also occurred in the form of changes in the interfacial properties. These tests were conducted using an in-situ SEM indentation apparatus (Touchstone Ltd., West Virginia, USA). The thickness of the specimens (2 samples for each condition) was $340 \mu \mathrm{m}$. A diamond indenter was used to apply the load to the fibres at a displacement rate of $0.18 \mu \mathrm{m} / \mathrm{s}$. Figure 3 shows the indenter acting on a SiC Nicalon fiber in an as-received sample. The apparatus offered high accuracy for the indenter positioning, allowed the push-out process to be carried out without fiber or matrix damage. Twenty fibers were indented on each sample and the average interfacial debonding shear strength $\left(\tau_{d b}\right)$ and the interfacial friction shear stress $\left(\tau_{f r}\right)$, which are the parameters characterizing the interface [21,22], were determined. A complete description of the indentation push-out technique and details concerning the calculation of the stresses are presented elsewhere [22,32]. SEM of polished sections of as-received and thermally shocked samples was employed to characterize the microstructure of the specimens.

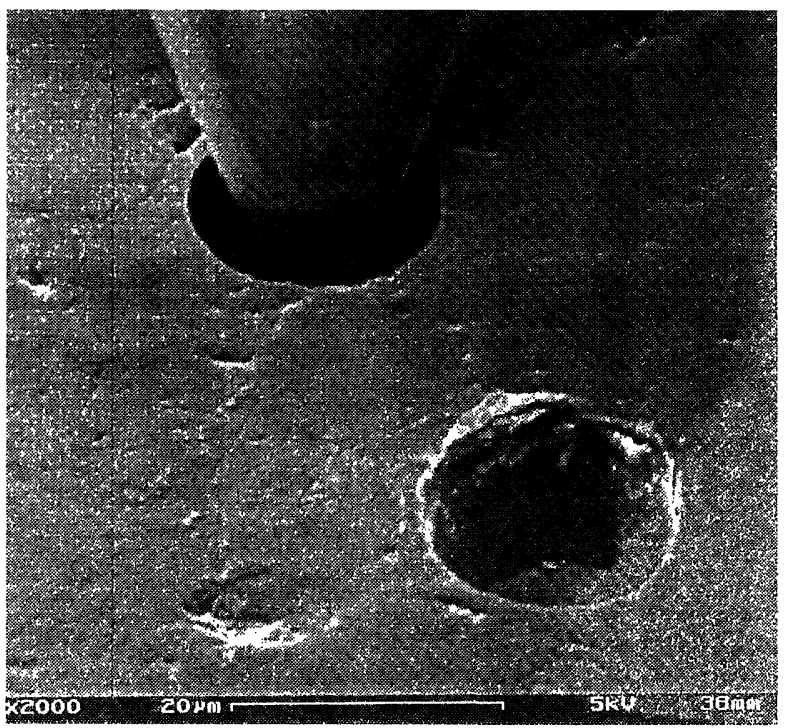

Fig. 3.- Micrografia (MEB) mostranco la punta de ia cuña actuando sobre una fibra de SiC en una probeta antes del ensayo de choque térnico.

Fig. 3. - SEM image showing the indenter acting on a SiCfiber in an asreceived sample (push-out test). 


\section{RESULTADOS}

La figura 4 muestra una micrografia de MEB de una sección pulida de una muestra sin ensayar. El material de la matriz se muestra denso, sin porosidad residual aparente y con una distribución regular de las fibras. Los resultados de las inediciones del módulo de Young y de la fricción interna de las muestras sometidas a choque térmico, obtenidos por la técnica de resonancia forzada, se muestran en la fgura 5. Los valores del módulo de Young están dados en forma de valores relativos, es decir, normalizados con respecto al valor del módulo de Young de las muestras sin ensayar (120 $12 \mathrm{GPa}$ ). Los ensayos sucesivos de choque térmico fueron finalizados cuando la variación de $E$ y $Q^{-1}$ correspondió al inicio de degradación del material. Esto ocurre cuando la fricción interna aumenta hasta un cierto valor, fijado arbitrariamente en el $100 \%$ del valor incial. Para las presentes condiciones de choque térmico, este hecho tiene lugar después de 21 ensayos. Es interesante notar que el módulo de Young disminuye solamente un $1 \%$ para el mismo número de ensayos. Esto indica que la fricción interna tiene una mayor sensibilidad para la determinación de daño microestructural, de acuerdo también con numerosos resultados encontrados en la literatura [33-37]. El error experimental en el que se incurre en la determinación de los cambios en el módulo de Young con respecto a las muestras sin ensayar es menor del $0,05 \%$. Este valor del error garantiza que cualquier cambio medido en la frecuencia de resonancia puede ser atribuido a cambios microestructurales ocurridos como resuitado de los procesos de daño por

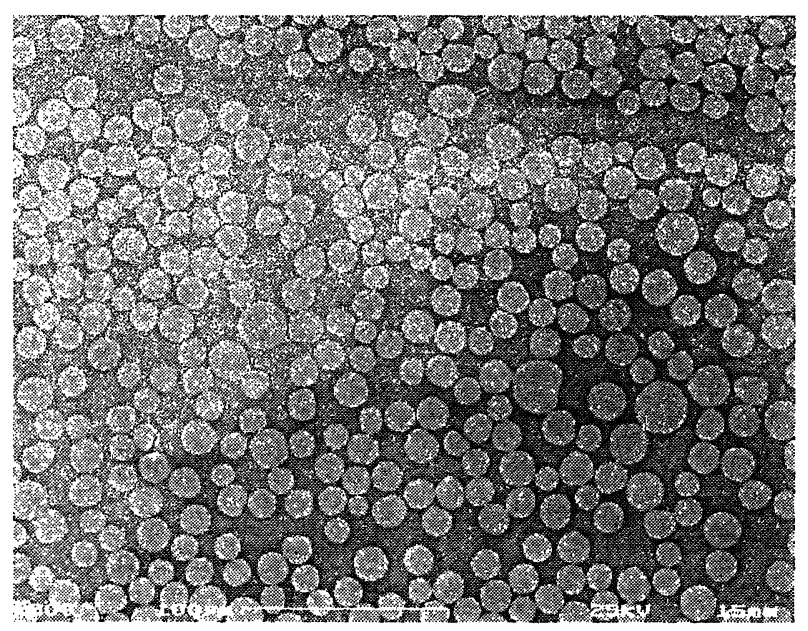

Fig. 4.- Micrografia (MEB) mostrando la sección pulida de una probeta del material compuesto investigado (matriz: vidrio borosilicato DURAN fibras: $\mathrm{SiC}-\mathrm{Nicalon}^{\mathrm{TM}}$ ). Se observa una distribución regular de fibras y ausencia de porosidad.

Fig. 4.- SEM micrograph showing the polished section of an as-received sample (matrix: borosilicate DURAN glass, fibers: SiC-Nicalon ${ }^{T M}$ ). A fairly homogeneous distribution of fibers and absence of porosity is observed.

\section{PESULTS}

Figure 4 shows an SEM micrograph of a polished section from an as-received sample. The matrix material appears dense, with no apparent residual porosity. A regular distribution of fibers is also evident. The results of the non-destructive deternination of the Young's mociulus and internal friction of thermally shocked sampies are given in figures. The data for the loung's modulus shown have been normalized to the as-received value $(120 \pm 2 \mathrm{GPa})$. The quench tests were jinished at the first innication of material degradation, arbitrarily defined to be when the internal fricion increased by approximately $100 \%$, which occurred after 21 cycies. The Young's modulus over this period decreased by only $1 \%$, illustrating the higher sensitivity of internal friction for damage detection, as also found in the literature [33-37]. The experimental error in the determination of changes in the Young's modulus from the as-received state was determined to be less than $0.05 \%$. This very small error ensured that any measured changes in the resonant frequency could be attributed solely to microstructural changes occurring as a result of thermal-shock damage, and not to experimental variations. The internal friction data were subject to a greater experimental error,

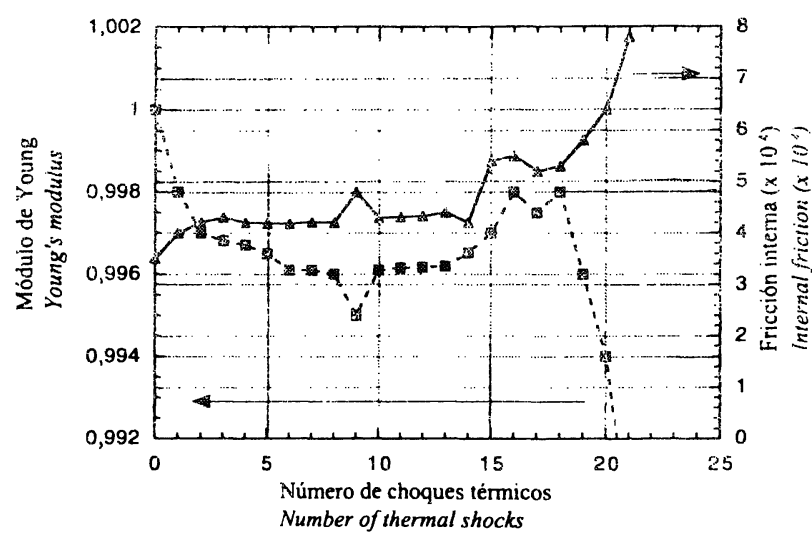

Fig. 5.- Variación del módulo de Young (a) y de la fricción interna (b), medidos por la técnica de resonancia forzada, en función del número de choques térmicos $\left(\Delta \mathrm{T}=630^{\circ} \mathrm{C}\right)$. Los valores del módulo de Young se han normalizado con respecto al valor del material sin ensayar $\left(\mathrm{E}_{0}=120 \mathrm{GPa}\right)$.

Fig. 5.- The variation of the Young 's modulus (a) and the internal friction (b) as a function of the number of thermal shocks $\left(\Delta T=630^{\circ} \mathrm{C}\right)$. The values of the Young's modulus have been normalized to the value of the as-received material $\left(E_{0}=120 \mathrm{GPa}\right)$. 
choque térmico y no a variaciones experimentales. Los datos de fricción interna están sometidos a un error experimental más grande, de aproximadamente el $5 \%$ [23].

La tabla II muestra el resumen de las mediciones de indentacion ("push-out") de fibras en muestras sin ensayar y en muestras sometidas a 21 ciclos de choque térmico. La calidad de la interfase viene dada por el valor de la resistencia a la fricción $\left(\tau_{\mathrm{fr}}\right)$ de la interfase, la cual permanece constante aun después de los 21 ciclos térmicos $\left(\tau_{\mathrm{fr}}=14 \pm 1 \mathrm{MPa}\right)$. Los valores de la tensión de corte de unión de la interfase $\left(\tau_{\mathrm{db}}\right)$ están, asímismo, poco influidos por el choque térmico, como se observa en la tabla I. Se determinó un valor medio de $\tau_{\mathrm{db}}=21 \mathrm{MPa}$ para las muestras sin ensayar y de $\tau_{\mathrm{db}}=24 \mathrm{MPa}$ para las muestras ensayadas. Sin embargo, hay una variación mayor de los datos medidos para la muestra sometida a choques térmicos (con una desviación standard de 10 $\mathrm{MPa}$ ). Las razones de este comportamiento se dan en la siguiente sección. determined to be $\sim 5 \%$ [23]. This was not seen to be a problem, however, as the measured changes in internal friction were of a much greater magnitude, as figure 5 shows.

In table II a summary of the fiber push-out measurements is presented for an as-received and a themally shocked sample (after 21 cycles). The quality of the interface is given by the value of the interfacial frictional shear stress $\left(\tau_{f r}\right)$, which is seen to remain unchanged after the thermal shocks. The values of the debonding shear stress $\left(\tau_{d b}\right)$ were also little influenced by thermal shocks: the mean values for the as-received and for the thermally shocked samples were $21 \mathrm{MPa}$ and $24 \mathrm{MPa}$, respectively. However, a greater scatter of the data was observed for the thermally shocked sample (standard deviation: $10 \mathrm{MPa}$ ). The reasons for this behavior are given in the next section.

TABLA \| (TABLE II)

Propiedades de la interfase fibra/matriz (Fiber/matrix interfacial properties)

\begin{tabular}{||l|c|c||}
\hline \multicolumn{1}{|c|}{$\begin{array}{c}\text { Propiedad } \\
\text { (Property) }\end{array}$} & $\begin{array}{c}\text { Mespués de choque térmico } \\
\text { (21 ciclos) } \\
\text { (As-received) } \\
\text { (Thermally shocked) } \\
\text { (21 shocks) }\end{array}$ \\
\hline $\begin{array}{l}\text { Resistencia de la interfase a la } \\
\text { fricción }\left(\boldsymbol{t}_{\mathrm{fr}}\right) \text { (MPa) } \\
\text { (Frictional shear strength) }\end{array}$ & $14 \pm 1$ & $14 \pm 1$ \\
\hline $\begin{array}{l}\text { Resistencia a la rotura de la } \\
\text { unión fibra/matriz }\left(\boldsymbol{t}_{\mathrm{db}}\right) \text { (PMa) } \\
\text { (Debonding strength) }\end{array}$ & $21 \pm 2$ & $24 \pm 9$ \\
\hline
\end{tabular}

\section{DISCUSIÓN}

\subsection{Evaluación del comportamiento al choque térmico}

El incremento en la fricción interna en paralelo con la disminución del módulo de Young, como se muestra en la figura 5, indican el desarrollo de un daño microestructural en el material por la creación de superficies internas nuevas en su interior. Estas se forman, por ejemplo, por el desarrollo de microgrietas en la matriz y/o como resultado de la degradación de la interfase. El desarrollo progresivo de microgrietas en la matriz puede esperarse debido al efecto acumulativo de las tensiones térmicas generadas por los sucesivos choques térmicos. De cualquier modo, no fueron

\section{DISCUSSION}

\subsection{Evaluation of thermal shock behavior}

An increase in internal friction, coupled with a simultaneous decrease in the Young's modulus, as shown in figure 5, indicate the development of microstructural damage, e.g. creation of new internal surfaces, for example by matrix microcracking or fiber debonding. In the present case, progressive microcrack development in the matrix is expected, due to the cumulative effect of the thermal stresses generated by successive quenchings. However, neither large. 
observadas ni macrogrietas ni delaminación macroscópica de las muestras en dirección paralela a las fibras, indicando que el daño en las muestras para las condiciones estudiadas es microscópico.

Se ha demostrado en un estudio paralelo sobre el mismo material [11], que choques térmicos de hasta $\Delta \mathrm{T}=570^{\circ} \mathrm{C}$ no causan daño microestructural en estos materiales compuestos, al menos hasta unos 21 ensayos, mientras que choques térmicos severos $\left(\Delta \mathrm{T}>690^{\circ} \mathrm{C}\right)$ producen una seria degradación microestructural en forma de grietas macroscópicas y delaminación, intensificándose este daño por la oxidación de la interfase. No se detectó delaminación macroscópica, ni cambios de masa en las muestras del presente estudio, donde el gradiente térmico fue intermedio $\left(\Delta \mathrm{T}=630^{\circ} \mathrm{C}\right)$. Por lo tanto, puede desecharse la posibilidad de una oxidación significativa de la interface. Consecuentemente, la disminución en un 1\% del módulo de Young y el incremento del $100 \%$ de la fricción interna se atribuyen, después de 21 choques térmicos, a la degradación del material causada solamente por el desarrollo de microgrietas en la matriz. Éstas son el producto de las tensiones internas que se generan a través del espesor de las probetas, como resultado de los sucesivos choques térmicos. Al ser sumergidas bruscamente en agua desde alta temperatura, las superficies de las probetas se enfrían más rápidamente que el interior, originado tensiones de tracción en la superficie y de compresión en el interior. Cuando esas tensiones de tracción alcanzan un valor crítico dado, se generan microgrietas, primero en la zona periférica de las probetas, que luego se propagan hacia el interior con sucesivos choques térmicos. Este comportamiento ha sido observado por otros autores, investigando la resistencia al choque térmico de distintos materiales cerámicos compuestos [2-8,10,12-16]. Por lo antes expuesto, no se esperan modificaciones significativas del resto de los constituyentes del material compuesto, es decir en la interfase o en las fibras, para el gradiente térmico investigado $\left(\Delta \mathrm{T}=630^{\circ} \mathrm{C}\right)$. Comparando los resultados de las mediciones de indentación de fibras ("push-out") en muestras sin ensayar y en muestras sometidas a choques térmicos (Tabla II), se puede confirmar que la interface no ha sufrido cambios significativos como consecuencia de los sucesivos choques térmicos. Esto se demuestra cuantitavamente teniendo en cuenta la constancia del valor de la resistencia a la fricción $\left(\tau_{\mathrm{fr}}\right)$ de la interface $\left(\tau_{\mathrm{fr}}=14 \pm 1 \mathrm{MPa}\right)$ y por el hecho de que los valores de la tensión de unión de la interfase han sido apenas influidos por el choque térmico: $\tau_{\mathrm{db}}=$ $21 \mathrm{MPa}$ para las muestras sin ensayar y $\tau_{\mathrm{db}}=24$ $\mathrm{MPa}$ para las muestras ensayadas. La variabilidad mayor de los datos medidos para las muestras sometidas a choques térmicos (con una desviación macrocracks nor serious delamination parallel to the fibre axes were observed in the present samples.

It was shown in a parallel study on the same material [11], that thermal shock of up $\Delta T=570^{\circ} \mathrm{C}$ do not cause any microstructural change in the material, for at least 21 cycles, whereas more severe thermal gradients $\left(\Delta T>690^{\circ} \mathrm{C}\right)$, resulted in serious microstructural degradation in the form of macroscopical flaws and delamination, probably enhanced by fibre/matrix interface oxidation. Neither macroscopic delamination nor mass changes were detected for the conditions used in this study, where the thermal shocks were intermediate $\left(\Delta T=630^{\circ} \mathrm{C}\right)$. Thus, the possibility of significant interface oxidation occurrence can be ruled out. Consequently, the 1\% decrease in Young's modulus and the $100 \%$ increment in the internal friction after 21 thermal shock cycles can be attributed to material degradation solely due to matrix microcrack development. These are created as a consequence of the internal stresses generated through the thickness of the samples during the thermal shocks. When a hot sample is quenched in water at room temperature, the sample surfaces are cooled more quickly than the sample interior, originating tensile stresses at the surface and compressive stresses in the interior. When the tensile stresses reach a certain critical value, microcracks are generated, firstly in the periphery of the samples. These cracks growth into the sample interior with further thermal quenches. This behavior has been reported also for other thermally shocked brittle matrix composites [2-8, 10, 12-16]. Thus, no significant modifications of the rest of the composite constituents, the fibers and interfaces, are therefore expected for the thermal gradient investigated here $\left(\Delta T=630^{\circ} \mathrm{C}\right)$. Comparing the fiber push-out indentation results (Table II), it is possible to confirm that the interface has not been significantly affected as a consequence of the thermal shocks. Quantitatively, this can be confirmed by the constancy of the value of the interfacial frictional shear stress ( $\tau_{f r}=14 \pm 1 \mathrm{MPa}$ for both samples) and by the fact that the debonding shear strength $\left(\tau_{d b}\right)$ was also not significantly influenced by the thermal shock loading: a mean value $\tau_{d h}=21 \mathrm{MPa}$ was determined for the as received and $\tau_{d b}=24 \mathrm{MPa}$ for the thermally shocked sample. The larger distribution of the measured data for the thermally shocked specimen (standard deviation: $10 \mathrm{MPa}$ ), may be explained by the in-situ observations 
standard de $10 \mathrm{MPa}$ ) puede explicarse con las observaciones de MEB hechas "in-situ" durante el proceso de "push-out" de las diferentes fibras. Normalmente, las fibras fueron arrancadas de la matriz con el desarrollo simultáneo de grietas en ésta, como muestra la figura 6 . Se observaron diferentes grados de agrietamiento, los cuales explican los diferentes valores de la tensión de corte de unión de la interfase $\left(\tau_{\mathrm{db}}\right)$ que conducen a la gran variación de los datos. Este comportamiento no lo presentan los materiales compuestos sin ensayar, ya que en éstos no fueron observados microagrietamientos de la matriz durante el arrancado de fibras (ver Figura 3) y los resultados presentaron una reducida desviación standard. El diferente comportamiento de las fibras sometidas a choque térmico puede explicarse cualitativamente considerando la presencia de un campo residual e irregular de tensiones en el material, como resultado de los sucesivos choques térmicos. Se ha demostrado que la presencia de tensiones residuales tiene una fuerte influencia en la propiedades de la interfase de materiales compuestos unidireccionales como los aquí investigados [38]. Estas tensiones inducidas dependen de los coeficientes de expansión térmica y de las propiedades elásticas de los constituyentes del material compuesto, como así también de los gradientes térmicos implicados en el choque térmico y de la distribución espacial de las fibras $[12,13,16]$. Más aún, el desarrollo de grietas en la matriz durante el arrancado de fibras (Figura 6) puede incrementarse por un mecanismo de unión de pequeñas microgrietas ya presentes en la región alrededor de la fibra cargada. Una investigación cuantitativa más detallada de este fenómeno está más allá de los objetivos del presente trabajo.

Un resultado importante de este estudio es el hecho de que la película interfacial de carbono en la interfase matriz-fibra no es degradada bajo las condiciones de choque térmico investigadas, ya que las propiedades interfaciales permanecen casi sin cambios. Además, la observación de superficies de fractura de muestras que habían sido sometidas a choques térmicos, permite confirmar que la interfase fibra/matriz no ha sufrido mayores cambios. La figura 7 muestra una de tales superficies de fractura. Se observa la existencia de "pull-out" de fibras, que es la característica de estos materiales cuando la interfase no ha sido degradada [10-13].

Debe destacarse que los materiales compuestos investigados en el presente trabajo mostraron una mayor resistencia al choque térmico que materiales similares estudiados por otros autores $[12,13]$. Una razón para este comportamiento es el muy bajo nivel de tensiones internas residuales creadas en estos materiales compuestos después del enfriamiento lento desde la temperatura de fabricación, ya que los coeficientes de of the push-out process of the different fibres. Typically, the fibres were pushed out with the simultaneous occurrence of crack development in the matrix, as shown in figure 6. Different degrees of cracking were observed, however, which resulted in the different values of the debonding shear strength, leading to the high data scattering. This behavior was not exhibited by the asreceived composites, as matrix microcracking during fibre push-out was never observed (Figure 3) and all tested fibers exhibited similar stress-displacement behavior. The different behaviour of single fibers in the thermally shocked sample can be explained qualitatively by considering that successive thermal shock cycles will introduce an uneven residual stress field in the material. It has been shown in the literature that the presence of residual stresses has a strong influence on the interfacial properties of unidirectional composites of the type investigated here [38]. These induced stresses depend on the thermal expansion and elastic properties of the composite constituents, the thermal gradients involved and the distribution of fibers $[12,13,16]$. Moreover, the development of matrix microcracking, as seen in figure 6 , can be increased by a coalescence mechanisms of small microcracks already present in the matrix in the region around the indented fiber. An in-depth microscopical investigation of these phenomena is beyond the scope of the present work.

Nevertheless, the important result to be highlighted here is the fact that the carbon-rich interfacial layer at the matrix/fibre interface, which provides the "composite" properties to the materal, i.e. the pseudo-ductile fracture behaviour, has not been degraded significantly under the thermal shock conditions investigated, as the interfacial properties remains largely unchanged. A further confirmation of the retention of non-catastrophic failure behavior after thermal shock is obtained by examination of fracture surfaces of thermally shocked samples fractured in 3-point flexural strength tests. Figure 7 is an example of such a fracture surface. Extensive fiber pull-out is observed, which is characteristic in this kind of materials when the interface has not been degraded [10-13].

The composites tested here showed an improved thermal shock resistance over similar materials tested by other authors [12,13]. One reason for this behaviour is the very low level of residual internal thermal stresses that develop in this material upon cooling from the fabrication temperature, since the thermal expansion coefficients of the matrix and 


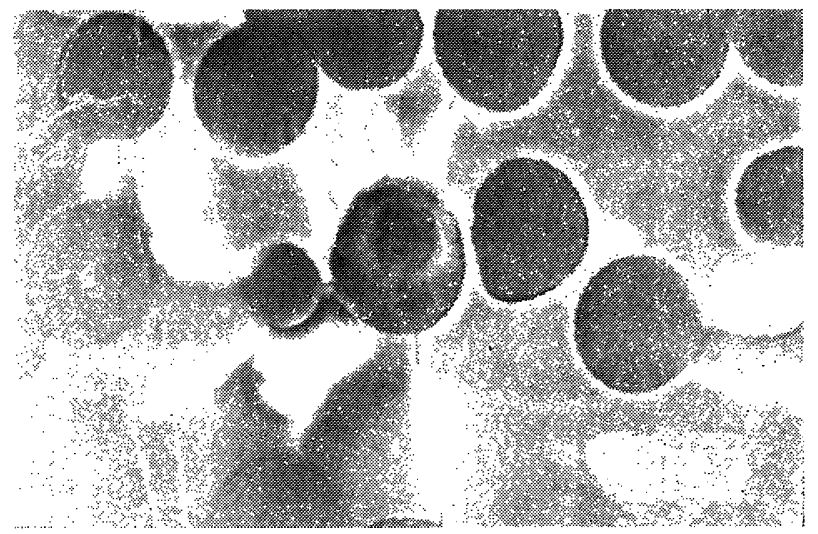

Fig. 6.- Micrografia (MEB) mostrando el hueco dejado por una fibra después de haber sido empujada fuera de la matriz en una probeta que había sido sometida a 21 ciclos de choque térmico. Se observa la formación de microgrietas en la matriz.

Fig. 6.- SEM micrograph showing the hole left by a fiber after having been pushed out of the matrix in a sample that had been subjected to 21 thermal shocks. Matrix microcracking around the indented area is observed.

expansión térmica de la matriz y de las fibras son muy similares (ver Tabla I). Se espera, por lo tanto, que las tensiones internas tangenciales y radiales creadas en la matriz sean bajas. En efecto, usando un modelo de cilindros concéntricos, Klug y col. [12] encontraron que las tensiones tangenciales y radiales en la interfase en este material compuesto son menores que $20 \mathrm{MPa}$.

La ausencia de cristalización de la matriz (formación de cristobalita) durante el proceso de fabricación del material $[12,26]$ y bajo las condiciones de choque térmico empleadas en este trabajo [11], es otro aspecto beneficioso de estos materiales compuestos, en comparación con otros compuestos de matriz de vidrio borosilicato registrados en la literatura. Por ejemplo, en su estudio sobre el comportamiento de materiales compuestos de matriz de vidrio Pyrex con refuerzo de fibras de carburo de silicio (Nicalon $^{\mathrm{TM}}$ ), Shin y col. [13] encontraron que el microagrietamiento de la matriz aumentaba por la formación de cristobalita. Esta fase cristalina, que tiene un coeficiente de expansión térmica mayor que el de la matriz amorfa, produce elevadas tensiones internas durante el enfriamiento de las piezas desde la temperatura de fabricación [13], lo que da lugar a un marcado microagrietamiento.

En síntesis, para el material presente y en las condiciones de choque térmico investigadas, la disminución del módulo de Young y el incremento simultáneo en la fricción interna (Figura 5) pueden atribuirse exclusivamente al progresivo microagrietamiento de la matriz de vidrio por los choques térmicos sucesivos desde $650^{\circ} \mathrm{C}$, que ocurren debido a las tensiones térmicas transitorias inducidas en el material compuesto.

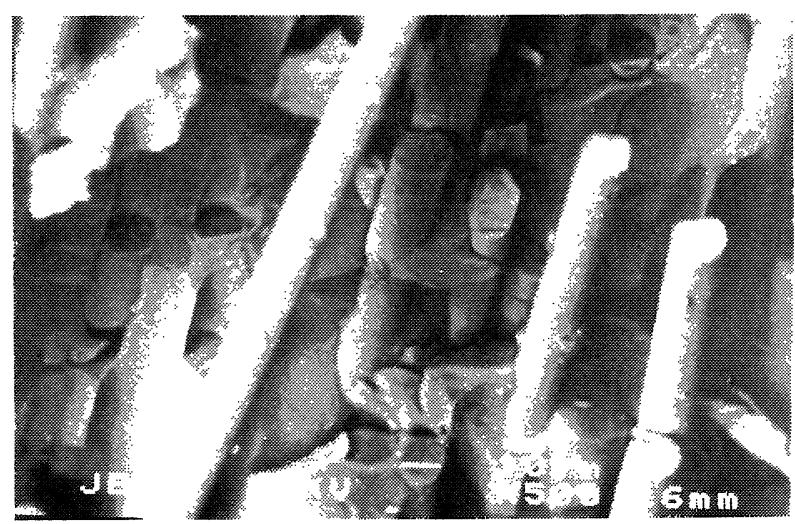

Fig. 7.- Superficie de fractura (MEB) de una muestra sometida a choques térmicos (21 ciclos) después de haber sido fracturada en un ensayo de flexión de tres puntos. Nótese la existencia de "pull-out" de las fibras, lo que indica que la interfase fibra/matriz no ha sido degradada durante los choques termicos.

Fig. 7.- Fracture surface of a thermally shocked (21 cycles) sample after having been fractured in 3-point bending test. Note the existence of fiber pull-out indicating that the interface has not been degraded during thermal shock

fibre are very close (see table 1). In fact, in their calculation using a simplified coated cylinder model applied to the present composites, Klug et al.[12] found the tangential and radial stresses at the interface to be less than $20 \mathrm{MPa}$.

The absence of matrix crystallisation (cristobalite formation) upon cooling from the fabrication temperature [12,26], and for the thermal shock conditions used in this work, determined elsewhere [11], is a further beneficial aspect of the present composites in comparison with similar materials studied in the literature. For example, in their study on the thermal shock behaviour of Nicalon ${ }^{T M}$ SiC fibre/Pyrex glass matrix composites, Shin et al. [13] found that microcracking development in the matrix upon thermal shock loading was enhanced by the formation of cristobalite. This crystalline phase, having a larger thermal expansion coefficient than that of the matrix, resulted in high thermal expansion mismatch stresses upon quenching from the heat-treatment temperature of $500{ }^{\circ} \mathrm{C}$ used in their study [13], thus leading to microcracking.

In summary, for the present borosilicate glass matrix composites, the decrease of the Young's modulus and simultaneous increase of internal friction (Figure 5), can be attributed to the progressive microcracking of the glass matrix, which occurs due to the transient thermal stresses induced by the thermal shocks from $650^{\circ} \mathrm{C}$. 


\subsection{Relación entre el nivel de fricción interna y el grado de agrietamiento de la matriz}

Los resultados presentados en la figura 5 demuestran que la fricción interna es un parámetro muy sensible para detectar microgrietas en un material compuesto. A esta misma conclusión se llega analizando datos publicados en la literatura [33-37]. Por lo tanto, es sumamente importante contar con una herramienta analítica que permita relacionar cuantitaivamente el valor de la fricción interna medido con el grado de microagrietamiento presente en el material. Una revisión de la literatura especializada arrojó el resultado de que tal modelo teórico no existe y sólo relaciones empíricas o semi-empíricas han sido propuestas. Un ejemplo es el modelo de Case y col. [36,37], que se basa en la relación entre el grado de microagrietamiento y el módulo de Young derivada por Budianski y O'Connell [39]. Sin embargo, este modelo es válido para materiales isotrópicos solamente $\mathrm{y}$, por lo tanto, no aplicable a los presentes materiales compuestos. Otra relación ha sido derivada por Boccaccini y col. [20], y es aplicable a materiales compuestos reforzados con fibras del tipo del material investigado aquí. El modelo considera un material compuesto agrietado con microgrietas perpendiculares a la dirección de las fibras y espaciadas regularmente. También tiene en cuenta la existencia de descohesión entre la interfase matriz-fibra, dada por la longitud característica $\left(L_{d}\right)$ que puede variar entre $L_{d}=0$, para el caso en que las fibras permanezcan ligadas a la matrix, y $L_{d}=L_{c}$, donce $L_{c}$ es la distancia crítica entre grietas en la matrix, para el caso de completa descohesión de la interfase. La expresión final es [20]:

\subsection{Correlation between the internal friction level and the extent of matrix microcracking}

The results shown in figure 5 demonstrate that the internal friction is a very sensitive parameter to detect microcracking in a composite material. The similar conclusion is reached by analyzing data published in the literature on several materials [33-37]. Thus, it would be very useful to count with a model linking quantitatively the internal friction value with the extent and characteristics of microcracking. A review of the open literature on the subject suggests that such a theoretical correlation does not exist, and only empirical or semi-empirical correlations have been proposed. One example is the approach of Case et al. [36,37], based on the relationship between microcrack density and Young's modulus derived by Budiansky and O'Connell [39]. However, this last approach is valid only for isotropic materials, and therefore it should not be applied to fiber reinforced composites. Another relationship, applicable to unidirectional composites, has been presented by Boccaccini et al. [20]. This approach considers a microcracked composite with cracks oriented perpendicularly to the fiber direction and regularly spaced. It also takes into account the existence of fiber/matrix decohesion, characterized by the characteristic debonding length $\left(L_{d}\right)$, which can vary between $L_{d}=0$, for fibers perfectly bonded to the matrix, and $L_{d}=L_{c}$, where $L_{c}$ is the critical spacing between matrix microcracks, for complete interfacial debonding. The final expression is [20]:

$$
\frac{Q^{-1}}{Q_{0}^{-1}}=1+C\left\{1-\frac{1}{1+2 k\left[L_{d} \xi+\frac{\xi}{\beta} \tanh \beta\left(\frac{1}{2 \xi}-L_{d}\right]\right]}\right\}^{3}
$$

donde $Q^{-1}, Q_{0}^{-1}$ son los valores de fricción interna del material conteniendo microgrietas y del material libre de microgrietas, respectivamente y $\xi$ es la densidad lineal de microgrietas (número de grietas por unidad de longitud). El parámetro $C$ es una constante de ajuste. Los parámetros $k$ y $\beta$ dependen de la geometría del material compuesto y de las propiedades de las fibras y la matriz, estando dados por: where $Q^{-1}, Q_{0}^{-1}$ are the values of the internal friction for the microcracked and the microcracked-free material, respectively, and $\xi$ is the lineal microcracking density (number of microcracks per length unit). The parameter $C$ is a fitting constant. The parameters $k$ and $\beta$ depend on microstructural features of the composite and on the properties of the matrix and the fibers, and are given by:

$$
\begin{gathered}
\beta=\frac{1}{r_{0}}\left(\frac{2 E_{c}}{E_{m}\left(1+v_{m}\left(\ln \frac{1}{V_{f}}+V_{f}-1\right)\right.}\right)^{1 / 2} \\
k=\frac{E_{m}\left(1-V_{f}\right)}{E_{f} V_{f}}
\end{gathered}
$$


donde $E_{m}, E_{\rho} E_{c}$ son los módulos de Young de la matriz, las fibras y el material compuesto, respectivamente, $V_{f}$ es la fracción volumétrica de fibras, $r_{0}$ es el radio de las fibras, $v_{m}$ es el número de Poisson de la matriz. La figura 8 muestra la variación de la fricción interna

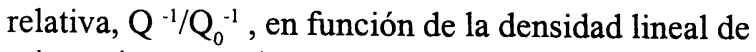
microgrietas para los materiales compuestos aquí investigados. La curva se ha calculado considerando una longitud de descohesión de la interfase $L_{d}=1 \mu \mathrm{m}$ y utilizando un parámetro de ajuste $C=200$. El modelo predice un incremento monótono de $\mathrm{Q}^{-1} / \mathrm{Q}_{0}{ }^{-1}$ con el aumento de la densidad de grietas de la matriz, en amplio acuerdo con los datos experimentales (Figura 5). Sin embargo, una verificación experimental rigurosa del modelo requerirá la medición de la densidad de microgrietas en las muestras dañadas por técnicas de microscopía óptica o electrónica, siendo éste el objeto de estudios actuales.

La posibilidad de correlacionar los valores de fricción interna medidos no-destructivamente con el grado de agrietamiento de la matriz es también importante teniendo en cuenta que estos materiales de matriz vítrea permiten el curado térmico de las grietas. En efecto, las microgrietas se pueden "reparar" en estos materiales por medio de un tratamiento térmico adecuado, usando el mecanismo de flujo viscoso en el vidrio, como lo han sugerido diferentes autores $[12,16,40]$. De esta manera, la detección temprana del daño inducido por choque térmico en forma de microgrietas en la matriz por medio de técnicas no destructivas adquiere una gran importancia en la práctica. Por ejemplo, un material estructural podría ser sometido a un tratamiento térmico adecuado para restaurar su integridad microestructural al detectarse un cambio en la fricción interna, y así su vida en servicio podría ser prolongada. where $E_{m}, E_{\rho} E_{c}$ are the Young's moduli of the matrix, the fibers and the composite, respectively, $V_{f}$ is the fiber volume fraction, $r_{0}$ is the fiber radio and $v_{m}$ is the Poisson's ratio of the matrix. Figure 8 shows the variation of the relative internal friction, $Q^{-1} / Q_{0}^{-1}$, as a function of the lineal microcrack density for the present thermally shocked composites. The curve was calculated considering a fixed debonding length, $L_{d}=1 \mu \mathrm{m}$, and with $C=200$. The model predicts $a$ monotonic increase of $Q^{-1} / Q_{0}^{-1}$ with increasing microcrack density, in agreement with the experimental results (figure 5). However, a rigorous experimental verification of the model will need the independent measurement of the microcrack density in thermally shocked samples, for example by optical or scanning electron microscopy, this being the subject of current research.

The possibility of relating internal friction data, measured non-destructively, with the level of matrix microcracking has a great practical relevance taking into account that matrix microcracks can be healed in glassy materials. Indeed, it is possible to heal microcracks in glass, exploiting its viscous flow properties, by a suitable annealing heat-treatment, as suggested by several authors [12,16,40]. Thus, the early non-destructive detection of thermal shock induced damage in the form of matrix microcracks acquires a major practical significance. For example, upon detecting a significant change in internal friction, a given component could be submitted to a heattreatment to restore its structural integrity and thus prolong its life in service.

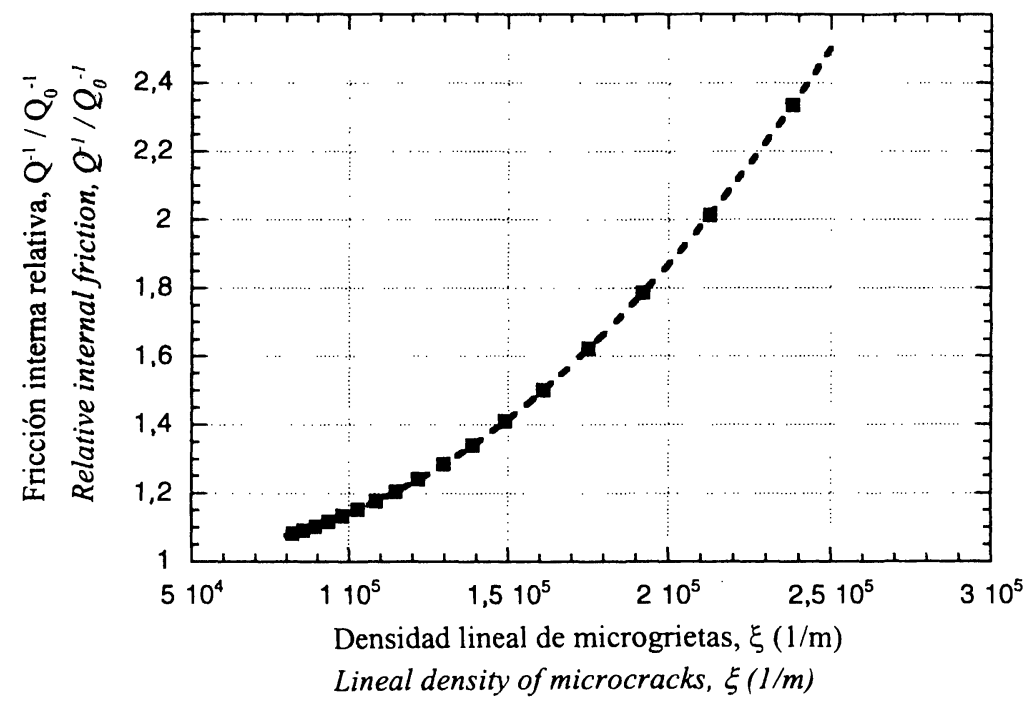

Fig. 8.- Curva teórica de la variación de la fricción interna relativa con la densidad lineal de microgrietas (Ec. 2) de acuerdo al modelo de Boccaccini y col. [20].

Fig. 8.- Theoretical curve for the variation of the relative internal friction with the lineal density of microcracks (Eq. 2), according to the model of Boccaccini et al. [20]. 


\section{CONCLUSIONES}

El comportamiento al choque térmico de materiales compuestos de matriz de vidrio reforzados con fibras de carburo de silicio ha sido investigado por enfriamientos bruscos en agua a temperatura ambiente de probetas calentadas previamente a $650^{\circ} \mathrm{C}$. Se usaron mediciones del modulo de Young y de la fricción interna para detectar la aparición y el avance del daño microestructural inducido por los choques térmicos. Las observaciones condujeron a la conclusión de que después de un número determinado de choques térmicos (21), la única causa para los cambios medidos en el módulo de Young y en la fricción interna fueron las microgrietas generadas en la matriz. Éstas aparecen como consecuencia de las tensiones térmicas transitorias generadas en las muestras a causa del elevado gradiente térmico que se establece por el enfriamiento brusco a partir de altas temperaturas. Las propiedades interfaciales del material compuesto permanecieron inalteradas después de 21 choques térmicos, de acuerdo con las mediciones de indentación de fibras ("push-out"). La relación entre el valor de fricción interna y el grado de agrietamiento en estos materiales está cualitativamente de acuerdo con la predicción de un modelo semi-empírico derivado en un estudio anterior. Como el material presenta la posibilidad de "reparar" las microgrietas de la matriz mediante un tratamiento térmico, aprovechando el flujo viscoso del vidrio, la detección temprana de este tipo de daño microestructural, antes de que la degradación del material haya avanzado en la interfase y en las fibras, adquiere especial importancia práctica. Esto permitiría, por ejemplo, prolongar la vida en servicio de estos materiales sometidos a choques térmicos.

\section{AGRADECIMIENTOS}

Las mediciones, usando la técnica de resonancia forzada, fueron efectuadas en la School of Metallurgy and Materials, University of Birmingham, Inglaterra, cuando dos de los autores, ARB y DNB eran investigador y estudiante visitantes, respectivamente. Los autores agradecen las interesantes discusiones mantenidas con el Dr. Clive B. Ponton y el apoyo recibido (The University of Birmingham). Tambien se agradece al Dr. W.Beier y al Sr. R. Liebald (Schott Glaswerke, Mainz, Alemania), por suministrar las muestras y por su interés en el presente trabajo.

\section{CONCLUSIONS}

The cyclic thermal shock behaviour of SiC-Nicalon fibre reinforced borosilicate glass matrix composite materials has been investigated by repeated quenching from $650^{\circ} \mathrm{C}$ into a room temperature water bath. Young's modulus and internal friction measurements enabled the detection of the onset and development of thermal shock induced damage. The observations suggest that after 21 thermal shock cycles the only cause of the observed changes in the Young's modulus and internal friction is matrix microcracking. These develop as a consequence of the transient thermal stresses generated in the samples by the large temperature gradient established upon quenching. The interfacial properties of the composite remain unchanged after 21 thermal shocks, as determined by push-out indentation tests. The correlation between the internal friction data and the extent of microcracking is in qualitative agreement with the prediction of a semiempirical model derived in a previous study. As glass matrices exhibit the possibility of microcrack healing by an annealing heat-treatment, exploiting a viscous flow mechanism, the early detection of this kind of damage before further degradation of the material has taken place, e.g. by interface or fiber oxidation, has especial practical significance. This would allow, for example, to prolong the life of components subject to thermal shock loading.

\section{ACKNOWLEDGEMENTS}

The forced-resonance tests were conducted at the School of Metallurgy and Materials, University of Birmingham, when two of the authors, $A R B$ and $D N B$, were visiting researcher and student, respectively. The authors acknowledge helpful discussions and the support of Dr. C. B. Ponton (School of Metallurgy and Materials, University of Birmingham, U.K.). Dr. W. Beier and Mr. R. Liebald (Schott Glaswerke, Mainz) are acknowledged for supplying the material and for their interest in this work.

\section{BIBLIOGRAFÍA}

[1] K. K. CHAWLA: Ceramic Matrix Composites, Chapman and Hall, London (1993).

[2] J. Ma . RINCÓN, P. CALLEJAS, J. RUBIO and J. L. OTEO, in: Ciencia y Tecnología de los Materiales Cerámicos y Vítreos. España'89. J. Ma. Rincón (Ed.), Ed. Faenza Editrice Ibérica and SECV (Castellón, 1990).

[3] R. N. SINGH and H. WANG, “Ceram. Eng. Sci. Proc.”, 16 (5), 699 (1995). 
[4] Y. KAGAWA, “Comp. Sci. Technol.”, 57 (5), 607 (1997).

[5] A. J. ECKEL, T. P. HERBELL, E. R. GENERAZIO, and J. Z. GYENKEYESI: “Ceram. Eng. Sci. Proc.”, 12 (7-8), 1500 (1991).

[6] R. N. SINGH and H. WANG: “Comp. Eng.”, 5 (10-11), 1287 (1995).

[7] R. T. BHATT and R. E. PHILLIPS: “J. Mat. Sci.”, 25, 3401 (1990).

[8] M. J. BLISSET, P. A. SMITH and J. A. YEOMANS: Thermal Shock Behaviour of Unidirectional Silicon Carbide Fibre Reinforced Calcium Aluminosilicate, "J. Mat. Sci”. 32 (1997) 317-325.

[9] Y. KIM, W. J. LEE and E. D. CASE, in: R. B. Bhagat, A. H. Clauer, P. Kumar and A. M. Ritter, eds., "Metal \& Ceramic Matrix Composites: Processing, Modeling and Mechanical Behaviour", The Minerals, Metals and Materials Soc., 1990, pp. 479-486.

[10] Y.KAGAWA, N. KUROSAWA and T. KISHI: Thermal Shock Resistance of SiCFibre-Reinforced Borosilicate Glass and Lithium Aluminosilicate Matrix Composites, “J. Mat. Sci.", 28 (1993) 735-741.

[11] A. R. BOCCACCINI, D. H. PEARCE, J. JANCZAK, W. BEIER and C. B. PONTON: Investigation of the Cyclic Thermal Shock Behaviour of Fibre Reinforced Glass Matrix Composites Using a Non-Destructive Forced Resonance Technique, "Mat. Sci. Technol". 13 (1997) 852-859.

[12] T. KLUG, J. REICHERT and R. BRÜCKNER: Thermal Shock Behaviour of SiC-Fibre Reinforeced Glasses, Glastech". Ber., 65, (1992) 41-49.

[13] D. W. SHIN, K. AUH and K. M. KNOWLES: “J. Ceram. Soc. Japan”, 103, 533 (1995).

[14] Y. KAGAWA, et al.: "Ceram. Eng. Sci. Proc"., 10 (9-10) 1327 (1989).

[15] Y. R. WANG and T. W. CHOU: “J. Mat. Sci.”, 26, 2961 (1991).

[16] L. P. ZAWADA AND R. C. WETHERHOLD: “Ceram. Eng. Sci. Proc.”, 10 (9-10) 1320 (1989).

[17] J. P. QIAN et al.: "J. Nucl. Mat.", 212-215, 1183 (1994).

[18] S. SATO, et al.: "Fusion Eng. Design", 13, 159 (1990).

[19] LAWRENCE, C. W., BRIGGS, G. A. D. , SCRUBY, C. B. and DAVIES, J. R. R.: Acoustic Microscopy of Ceramic Fibre Composites, "J. Mat. Sci.", 28 (1993) 3635-3644.

[20] A. R. BOCCACCINI, C. B. PONTON AND K. K. CHAWLA: "Mat. Sci. Eng”. A (1998) in press.

[21] R. J. KERANS, T. A. PARTHASARATHY, T. A.: Theoretical Analysis of the Fibre Pullout and Pushout Tests, "J. Am. Ceram. Soc.", 74 (1991) 1585-96.

[22] J. JANCZAK, G. BUERKI and L. ROHR: Interfacial Characterization of MMCs and CMCs using a SEM-Pushout Technique, "Key Eng, Mater". 127-131 (1997) 623-630.

[23] D. H. PEARCE: "Fabrication and Evaluation of an Oxide-Oxide Ceramic Matrix Composite“, PhD Thesis, School of Metallurgy and Materials, The University of Birmingham, 1996.

[24] W. BEIER, TOUGH and STRONG: "Schott-Information", 73 (1995) 3-6.

[25] A. R. BOCCACCINI, A. STRUTT, D. H. PEARCE and K. S. VECCHIO: Thermal shock and thermal cycling behaviour of fiber reinforced glass matrix composites. In: "Proc. 29th Int. SAMPE Technical Conference, Composites for the Real World". J. E. Green, S. W. Beckwith and A. Brent Strong (eds.), Society for the Advancement of Material and Process Engineering (SAMPE), Covina, CA (1997) pp.207-219.

[20] W. PANNHORST, M. SPALLEK, R. BRÜCKNER, H. HEGELER, C. REICH, G. GRATHWOHL, B. MEIER and D SPELMANN; Fiber-Reinforced Glasses and Glass-Ceramics Fabricated by a Novel Process, "Ceram. Eng. Sci. Proc". 11 (1990) 947-963.

[27] A. R. BOCCACCINI and M. KÖPF: Glashaltige Verbundwerkstoffe: eine Übersicht, "Berg. und Hüttenmännische Monatshefte" 141 [3] (1996) 110-121. 
[28] R. E. DUTTON, N. J. PAGANO and R. Y. KIM: Crack Initiation in Borosilicate Glass-SiC Fiber Composites, "J. Am. Ceram. Soc." 79 (1996) 865-72.

[29] A. HÄHNEL, E. PIPPEL and J. WOLTERSDORF: Nanostructure of Interlayers in Diffenrent Nicalon Fibre/Glass Matrix Composites and their Effect on Mechanical Properties, "J. of Mic." 177 (1995) 264-271.

[30] F. FÖRSTER: A New Method for the Determination of the Modulus of Elasticity and Damping, “Z. Metallk.", 29 (1937) 109115.

[31] D. H. PEARCE, A. J. JICKELLS, C. B. PONTON, C. B.: Fabrication of Sapphire Fibre Reinforced Ceramic Matrix Composite, "Br. Ceram. Trans." 95 (1996) 141-145.

[32] D. H. PEARCE, J. JANCZAK, A. R. BOCCACCINI, C. B. PONTON and L. ROHR: Characterisation of a pressureless sintered sapphire fibre reinforced mullite matrix composite, "Mat. Sci. Eng." A214 (1996) 170-173.

[33] J. C. GLANDUS and P. BOCH: Non Destructive Testing of Silicon Oxynitride Thermal Shock Sensitivity, pp. 661-670, in P. Vincenzini (ed.), "Energy and Ceramics: Proc. 4th Int. Meeting on Modern Ceramic Technologies", Elsevier, Amsterdam, 1980.

[34] J. A. COPPOLA and R. C. BRADंT: Thermal Shock Damage in SiC, “J. Am. Ceram. Soc.", 56 (1973) 214-218.

[35] K. MATSUSHITA, S. KURATANI, T. OKAMOTO and M. SHIMADA: Young's Modulus and Internal Friction in Alumina Subjected to Thermal Shock, "J. Mat. Sci. Lett." 3 (1984) 345-348.

[36] W. J. LEE and E. D. CASE: Thermal Fatigue in Polycrystalline Alumina, "J. Mat. Sci." 25 (1990) 5043-5054.

[37] W. J. LEE and E. D. CASE: Cyclic Thermal Shock in SiC-Whisker-Reinforced Alumina Composite, "Mat. Sci. Eng.", A119 (1989) 113-126.

[38] M. KUNTZ, B. MEIER and G. GRATHWOHL: Residual Stresses in Fibre-Reinforced Ceramics due to Thermal Expansion Mismatch, "J. Am. Ceram. Soc." 76 (1993) 2607. 12.

[39] B. BUDIANSKY and R. J. O'CONNELL: Elastic Moduli of a Cracked Solid, “Int. J. Solids Struct”. 12 (1975) 81-97.

[40] R. C. WETHERHOLD and L. P. ZAWADA: Heat Treatments as a Method of Protection for a Ceramic Fiber-Glass Composite, "J. Am. Ceram. Soc." 74 (1991) 1997-2000. 